\title{
The European research area network - E-Rare
}

\author{
Sophie Koutouzov \\ From 5th European Conference on Rare Diseases (ECRD 2010) \\ Krakow, Poland. 13-15 May 2010
}

Rare diseases represent an important public-health issue, affecting 26-30 million persons across Europe, and a major challenge for research. The fragmentation of resources and knowledge for the 6000-8000 rare diseases and the lack of efficient treatments for many of them necessitate a coordinated European approach to unravel the underlying molecular defects and pathophysiological mechanisms. The low number of affected patients requires transnational collaboration with multidisciplinary approaches to map prevalences, build patient registries, identify biomarkers, develop new diagnostics and finally perform clinical studies for the development of treatments. To this end, 8 main European research funding organisations have gathered into the PF6-funded EC ERA-Net on rare diseases (E-Rare) (2006-2010) and developed a number of joint activities regarding systematic exchange of information and best practises, definition of strategic priorities, and, most importantly, joint funding activities through the launch and completion of two fully fledged joint transnational calls for research projects on rare diseases (2007 and 2009). This exemplary joint funding activity has attested the need of, and the acknowledgment from, the research community for transnational funding of collaborative, multidisciplinary and ambitious projects on rare diseases. It has leveraged funding for rare disease research in countries that do not have specific programmes for rare diseases and thus enabled the participation of researchers in these countries to transnational projects. A new E-Rare project (E-Rare-2) (2010-2014) aims at deepening and extending the cooperation among the ERare- 1 and four new partner countries by systematic exchange of information, yearly launched joint calls, thorough assessment of the funding mechanisms and results of the funded research projects and, finally, strategic activities aiming at a sustainable development and

Correspondence: skoutouzov@gis-maladiesrares.net

GIS Maladies Rares, Plateforme Maladies Rares, 102 rue Didot, 75014 Paris, France extension of the network. Special attention will be given to the outreach and knowledge exchange with new Member States, countries outside of the European Union and key stakeholders/initiatives important for rare diseases. E-Rare-2 activities will thus further contribute to reducing fragmentation of research and resources through the enhanced coordination and transnational funding of excellent research on rare diseases, thereby shaping the European Research Area for rare diseases.

Published: 19 October 2010

doi:10.1186/1750-1172-5-S1-015

Cite this article as: Koutouzov: The European research area network E-Rare. Orphanet Journal of Rare Diseases 2010 5(Suppl 1):O15.
Submit your next manuscript to BioMed Central and take full advantage of:

- Convenient online submission

- Thorough peer review

- No space constraints or color figure charges

- Immediate publication on acceptance

- Inclusion in PubMed, CAS, Scopus and Google Scholar

- Research which is freely available for redistribution

Submit your manuscript at www.biomedcentral.com/submit
C Biomed Central 